\title{
PENERAPAN JUST IN TIME DALAM SISTEM PEMBELIAN DAN SISTEM PRODUKSI
}

\author{
Heri Sukendar W. \\ Jurusan Akuntansi, Fakultas Ekonomi \& Bisnis, Bina Nusantara University \\ Jln. K.H. Syahdan No. 9, Kemanggisan, Palmerah, Jakarta Barat 11480
}

\begin{abstract}
Just in Time is a management philosophy, techniques, or methods be comprehensive in order to buy raw materials and producing goods only when necessary and timely to be used at every stage we have available. Research was conducted by doing library research. Many problems faced by the industry, especially the existence of inefficiency in the system of purchasing and production. With the implementation of Just in Time, then the problem can be overcome and eventually going savings that will increase corporate profits.
\end{abstract}

Keywords: Just-In-Time, efficient, effective

\begin{abstract}
ABSTRAK
Just in Time adalah suatu filosofi manajemen, teknik, ataupun metode yang dilakukan secara komprehensif dengan tujuan untuk membeli bahan baku dan memproduksi barang hanya saat dibutuhkan dan tepat waktu untuk digunakan di setiap tahapan yang ada. Penelitian ini dilakukan dengan melakukan riset kepustakaan. Banyak masalah yang dihadapi oleh industri terutama adanya inefisiensi dalam sistem pembelian dan produksi. Dengan diterapkannya Just in Time, maka masalah tersebut dapat diatasi dan pada akhirnya terjadi penghematan yang akan meningkatkan laba perusahaan.
\end{abstract}

Kata kunci: Just-In-Time, Efisien, Efektif 


\section{PENDAHULUAN}

\section{Latar Belakang masalah}

Dengan begitu pesatnya kemajuan pada era globalisasi ini, persaingan antar perusahaan semakin ketat baik di dalam negeri maupun di luar negeri. Untuk dapat mempertahankan kelangsungan perusahaan dan meningkatkan pencapaian laba, maka perusahaan harus mampu menciptakan produk yang lebih baik dari pesaingnya. Hal ini dapat dicapai melalui peningkatan efisiensi perusahaan. Efisiensi ini dapat dilakukan dengan menekan biaya produksi, namun secara bersamaan tidak mempengaruhi kualitas barang yang diprosuksi.

Peningkatan efisiensi dapat dilakukan dalam berbagai kegiatan di dalam perusahaan yang mencakup pembelian bahan baku, proses produksi dan distribusi. Salah satunya adalah dengan melakukan pengelolaan persediaan dengan baik, karena persediaan memiliki peranan yang sangat penting. Kelebihan persediaan dalam suatu perusahaan akan mengakibatkan bertambahnya biaya pengelolaan persediaan tersebut. Sebaliknya, jika terjadi kekurangan persediaan, maka akan memperbesar resiko keterlambatan dalam kegiatan produksi.

Banyak metode yang dapat digunakan oleh perusahaan untuk mengelola persediaan yang dimiliki perusahaan, salah satunya adalah metode Just-In-Time. Just -In-Time adalah usaha untuk meningkatkan produktivitas dengan mengeliminasi pemborosan dalam segala bentuk (Hernandez, 1993). Sistem Just-In-Time pertama kali diperkenalkan oleh Taiichi Ohno, Executive Vice President of Toyota Motor Company, pada awal tahun 1950. Tujuan Ohno saat itu adalah agar Toyota dapat memproduksi berbagai macam produk agar sesuai dengan permintaan pelanggannya dengan penundaan yang seminimum mungkin (Modarress \& Ansari, 1990).

Just-In-Time tidak hanya sebuah teknik ataupun pendekatan, namun juga merupakan suatu filosofi dan strategi manajemen. Just-In-Time menganggap kelebihan persediaan sebagai pemborosan. Namun, mengurangi persediaan bukanlah tujuan utama dari Just-In-Time. Tujuan Just-In-Time adalah untuk meningkatkan produktivitas dengan cara mengurangi berbagai aktivitas yang tidak memberikan nilai tambah bagi produk. Just-In-Time juga mengharuskan perusahaan meningkatkan kualitas barang yang diproduksi, misalnya perusahaan juga harus memperhatikan jenis dan mutu dari material yang digunakan dalam proses produksi, mutu peralatan, dan mutu karyawannya (Hernandez, 1993). Just-InTime akan sukses jika penerapannya juga memperhatikan kualitas. Tanpa kualitas, Just-In-Time akan membawa perusahaan menjadi kacau.

Penerapan Just-In-Time dalam berbagai bidan fungsional perusahaan, namum paling banyak diterapkan dalam bidang pembelian dan produksi karena sistem pembelian dan produksi merupakan titik awal penerapan Just-In-Time sebelum diterapkan pada bidang fungsional lainnya.

\section{Perumusan Masalah}

Berdasarkan uraian di atas, maka penulis dapat merumuskan masalah penelitian ini sebagai berikut: (1) bagaimana proses penerapan Just-In-Time; (2) apa kendala yang dihadapi perusahaan dalam proses penerapan Just-In-Time.

\section{Tujuan Penelitian}

Adapun tujuan penelitian ini adalah untuk mengetahui: (1) proses penerapan Just-In-Time; (2) kendala yang dihadapi perusahaan dalam proses penerpan Just-In-Time. 


\section{METODE PENELITIAN}

Penelitian ini merupakan penelitian kualitatif dengan sistem analisis kepustakaan, dengan cara mencari informasi yang berhubungan dengan Just-In-time dari buku-buku, artikel, jurnal dan situs internet.

\section{Landasan Teori}

\section{Konsep Dasar Just-In-Time}

Konsep Just-In-Time menurut Blocher, Chen, \& Lin (2002) adalah: A Just-In-Time (JIT) system is a comprehensive production and inventory management system that purchases or produces materials and part only as needed and just in time to be used to each stage of production process. Menurut Hilton, Maher \& Selto (2000), konsep Just-In-time adalah: Just-In-Time is a process to purchase, make, and deliver products just when needed.

Menurut Narasimhan, McLeavey, \& Billington (1995), konsep Just-In-Time adalah: Just-Intime is often thought to be a technique for reducing inventories. That is only partly correct. Just-Intime can be considered in two ways: first, as a philosophy of waste reduction, and second, as a set of technique for the reduction of inventory and waste. Sedangkan konsep Just-In-Time menurut Heizer \& Render (2001) adalah: Just-In-time is a philosophy of continuous and forced problem solving that drives out waste.

Menurut Schniederjans (1993), Just-In-Time merupakan suatu pendekatan, metodologi, filosofi, konsep, dan juga strategi. Bannock, Baxter \& Davis (2003), mengemukakan konsep Just-Intime yaitu: Just-In-Time is a form of production management, originating in Japan, in which companies do not obtain stocks of component until they are actually needed. Modarress \& Ansari (1990) juga menambahkan bahwa: In order to have a pure Just-In-Time system, production and purchasing activities must be synchronized. In other words, the production system is not complete without adopting Just-In-time purchasing practices.

\section{Karakteristik Just-In-time}

Heizer \& Render (2001) mengemukakan karakteristik Just-In-Time dengan Tabel 1 di bawah ini.

Tabel 1 Karakteristik Just-In-Time

\begin{tabular}{ll}
\hline Supplier & $\begin{array}{l}\text { Reduced number of vendors; Supportive supplier relationship; Quality } \\
\text { deliveries on time }\end{array}$ \\
& Work-cell layout with testing at each step of the process; Group technology; \\
Layout & Movable, changeable, flexible machinery; High level inventory; Delivery \\
& directly to work areas. \\
& Small lot sizes; Low setup times; Specialized bins for holding set number of \\
Inventory & Zarts \\
& Zero deviation from schedules; Level schedules; Suppliers informed of \\
Scheduling & Schedules; Kanban techniques \\
& Scheduled; Daily routine; Operator involvement \\
Preventive Maintenance & Statistical process control; Quality suppliers; Quality within the firm \\
Euality Production & Empowered and cross-trained employess; Training support; Few job \\
Employee Empowerment & classifications to ensure flexibility of employees. \\
& Support of management; employees, and suppliers \\
\hline
\end{tabular}

Sumber: Heizer \& Render (2001) 
Dalam buku Introduction to Management Accounting karangan Horngren \& Stratton (2002) ditambahkan bahwa aktivitas yang tidak memberikan nilai tambah dapat dihilangkan atau dikurangi dengan cara berfokus pada kualitas, memperbaiki layout, dan pekerja multi-skilled. Selain itu, Hansen \& Mowen (2006), menambahkan bahwa kualitas juga merupakan tujuan utama dari perusahaan yang menerapkan Just-In-Time.

\section{Tujuan Penerapan Just-In-Time}

Menurut Modarress dan Ansari (1990), tujuan dari penerapan Just-In-time adalah untuk meningkatkan kualitas produk dan produktivitas dengan mengeliminasi pemborosan. Pemborosan ini dapat diartikan sebagai peralatan, bahan baku, dan pekerja. Arnaldo Hernandez (1993), menambahkan bahwa: Reducing inventories, however, is not the primary goal of Just-In-time. The primary goal is to increase the productivity of a manufacturing system by eliminating all kinds of activity that add no value to a product.

Menurut Blocher, Chen \& Lin (2002), tujuan dari penerapan Just-In-Time adalah untuk membeli bahan baku tepat waktu untuk digunakan dalam proses produksi, dan untuk memproduksi dan mengantarkan barang tepat waktu untuk dijual. Ini dapat dicapai dengan mengurangi pemborosan, mengurangi persediaan, membangun hubungan yang baik dengan pemasok, meningkatkan keikutsertaan pekerja, dan membuat program yang berfokus pada konsumen.

Mengenai hubungan dengan pemasok, Heizer \& Render (2001), menambahkan bahwa perlu adanya Just-In-Time partnership antara perusahaan dengan pemasok. Tujuan dari Just-In-Time partnership ini adalah untuk mengeliminasi aktivitas yang tidak perlu, mengeliminasi persediaan dalam pabrik, mengeliminasi persediaan dalam perjalanan, dan mengeliminasi pemasok yang tidak berkualitas. Tabel 2 menjelaskan karakteristik dari Just-In-Time partnership.

Tabel 2 Karakteristik Just-In-Time Partnership

\begin{tabular}{|c|}
\hline SUPPLIER \\
\hline $\begin{array}{l}\text { Few suppliers } \\
\text { Nearby suppliers } \\
\text { Repeat business with same suppliers } \\
\text { Competitive price }\end{array}$ \\
\hline QUANTITIES \\
\hline $\begin{array}{l}\text { Steady output rates } \\
\text { Frequent deliveries in small-lot size } \\
\text { Long term contract agreement } \\
\text { Minimal paperwork to release order } \\
\text { Supplier package in exact quantities }\end{array}$ \\
\hline QUALITY \\
\hline $\begin{array}{l}\text { Minimal product specifications imposed on supplier } \\
\text { Help suppliers to meet quality requirements }\end{array}$ \\
\hline SHIPPING \\
\hline Scheduling of inbound freight \\
\hline
\end{tabular}

Sumber: Heizer, Jay dan Barry Render. 2001.

Principles of Operations Management $6^{\text {th }}$ Edition, halaman 519.

Menurut Hansen \& Mowen (2003), tujuan penerapan Just-In-Time ada dua, yaitu: untuk meningkatkan keuntungan perusahaan dan memperbaiki posisi perusahaan. Keduanya dapat dicapai dengan mengontrol biaya, memperbaiki kegiatan pengantaran barang, dan meningkatkan kualitas. 


\section{Implementasi Just-In-Time}

Mengimplementasi Just-In-Time bukan merupakan pekerjaan yang mudah, sebagai contoh, Toyota membutuhkan waktu dua puluh tahun untuk mengimplemetasi Just-In-time. Petroff (1993) mengatakan hal-hal yang harus dilakukan untuk mengimplementasikan Just-In-time adalah: mengedukasi dan melatih manajer dan eksekutif; menjadikan kualitas sebagai prioritas; memperbolehkan pekerja dan mesin tidak bekerja saat tidak ada pekerjaan; menjadikan pekerja menjadi pekerja yang handal; mengadopsi pengukuran kinerja Just-In-time; mengatur persediaan dan safety stock dengan Just-In-Time. Selain itu, dalam buku tersebut juga disebutkan bahwa pemasok dan pekerja harus diperlukan sebagai bagian dari perusahaan yang penting, bukan sebagai musuh.

\section{Kelebihan Just-In-Time}

Berikut ini adalah kelebihan-kelebihan dari Just-In-Time menurut Silver, Pyke \& Peterson (1998): (1) reduced work-in-process inventory, and therefore less space and cost; (2) higher quality, due to continuous improvement efforts and to small lot sizes; (3) higher productivity; (4) short lead times; (5) low control costs due to the decentralized nature of the system; (6) less paperwork; (7) higher reliability of production because problem are visible; (8) visible, predictable amount of inventory, because inventory records of WIP and materials can be updated only when finished goods have been recorded into stock, so there is no need for complex WIP inventory tracking system.

Library of Congress Cataloging-Publication Data (1999) menambahkan kelebihan Just-InTime sebagai: (1) reduction of direct and indirect labor by eliminating extraneous activities; (2) reduction of floor space and warehouse space per unit of output; (3) reduction of setup time and schedule delays as the factory becomes a continuous production process; (4) reduction of waste, rejects, and rework by detecting errors at the source; (5) reduction of lead time due to small lot sizes, so that downstream work centers provide feedback on quality problems; (6) better utilization of machines and facilities; (7) better relation with supplier; (8) better plant layout; (9) better integration of and communication between functions such as marketing, purchasing, design, and production; (10) quality control built into the process.

\section{Kekurangan Just-In-Time}

Berikut ini adalah kekurangan-kekurangan Just-In-time menurut Hansen \& Mowen (2003): (1) dibutuhkan waktu yang lama agar dapat mengimplementasikan Just-In-Time dengan baik; (2) penerapan Just-In-Time dapat berpengaruh buruk terhadap pekerja karena adanya perubahan alur kerja yang drastic dengan tidak adanya persediaan; (3) munculnya resiko kekurangan barang dan kehilangan penjualan karena tidak ada persediaan yang banyak.

Silver, Pyke \& Peterson (1998), juga menambahkan kekurangan-kekurangan Just-In-Time yaitu Just-In-time sangat rapuh terhadap tutupnya pabrik, lonjakan permintaan, dan kejadian tidak menentu lainnya.

\section{PEMBAHASAN}

\section{Analisis Masalah Loss Bahan Baku}

Masalah loss bahan baku yang terjadi pada perusahaan tentu saja mengakibatkan terjadinya pemborosan. Pemborosan ini sangat tidak sesuai dengan prinsip Just-In-Time yang menekankan pada pentingnya efisiensi. Bahan baku yang digunakan oleh perusahaan kadang kali tidak sesuai dengan yang sebenarnya yang dapat dipergunakan, misalnya karena adanya kerusakan atau mengandung air sehingga saat ditimbang beratnya menjadi lebih berat daripada yang seharusnya. Selain itu, ada 
kalanya barang yang tidak dapat dijadikan bahan baku produksi namun tetap diterima, sehingga akan merugikan perusahaan karena barang tersebut akhirnya harus dibuang dan juga dibayar. Hal seperti ini tentu saja merugikan perusahaan, karena membayar lebih banyak dari yang seharusnya.

Pada saat penerimaan bahan baku, tentu saja akan dilakukan pemeriksaan terhadap bahan baku tersebut. Pemeriksaan ini bertujuan agar bahan baku yang diterima sesuati spesifikasi. Namun, pemeriksaan terhadap bahan baku tersebut terkadang tidak dilakukan dengan baik. Hal ini diakibatkan oleh kekurangan pengawasan terhadap kegiatan pemeriksaan tersebut. Kurangnya pengawasan mengakibatkan pemeriksaan tidak dilakukan dengan baik dan teliti. Selain itu, para pemeriksa harus diberikan pengetahuan lebih mengenai barang-barang yang tidak dapat dijadikan bahan baku produksi sehingga jika ada barang-barang yang tidak sesuai, maka barang-barang tersebut dapat ditolak. Pengalaman yang dimiliki oleh para pemeriksa juga dapat digunakan untuk mengurangi resiko loss bahan baku yang terjadi.

Kerugian yang dapat dikatakan pemborosan ini dapat diminimalkan dengan diterapkannya prinsip Just-In-time dalam perusahaan. Sesuai dengan prinsip Just-In-time yang menekankan pada sedikitnya jumlah persediaan yang dimiliki oleh suatu perusahaan, maka masalah loss bahan baku ini sangat tepat dipecahkan dengan prinsip Just-In-Time. Dengan Just-In-Time maka perusahaan harus mengurangi jumlah pemasok bahan baku. Sebelum para pemasok dipilih, harus dilakukan penilaian terhadap para pemasok tersebut. Pemasok yang dipilih adalah pemasok yang tidak merugikan perusahaan. Kriteria dalam memilih pemasok tersebut antara lain adalah pemasok yang tingkat loss bahan bakunya paling sedikit, pemasok yang memberikan harga yang paling kompetitif, pemasok yang bahan bakunya berkualitas baik, pemasok yang mendukung kegiatan perusahaan, yang lokasinya tidak jauh dari perusahaan dan selalu tepat waktu dalam pengiriman bahan baku. Setelah para pemasok dipilih, antara perusahaan dan para pemasok tersebut harus dibuat kontrak jangka panjang, yang nantinya mendukung upaya perusahaan dalam penerapan Just-In-Time. Dalam kontrak jangka panjang tersebut, diatur mengenai: harga bahan baku, spesifikasi minimum bahan baku, kuantitas bahan baku tiap pengiriman, dan alat transportasi pengiriman.

Hal-hal yang diatur dalam kontrak jangka panjang antara perusahaan dan para pemasok bertujuan untuk membantu perusahaan dalam menerapkan Just-In-Time, misalnya dengan menentukan harga bahan baku sebelumnya, maka perusahaan tidak perlu memikirkan kenaikan harga bahan baku, adanya spesifikasi minimum membuat inspeksi saat penerimaan bahan baku dapat dikurangi sehingga mempercepat proses produksi. Selain itu, dengan kuantitas yang telah ditetapkan sebelumnya maka perusahaan tidak perlu memiliki gudang penyimpangan bahan baku yang terlalu banyak karena bahan baku yang dikirim langsung digunakan dalam proses produksi, sehingga dapt mengurangi biaya dan tempat. Alat transportasi pengiriman juga perlu ditentukan agar pengiriman bahan baku dapat dilakukan tepat pada waktunya. Dengan adanya ikatan kontrak jangka panjang, maka proses pembelian yang berbelit dan memakan waktu lama dengan menggunakan kertas-kertas dapat diganti dengan melakukan pemesanan melalui telepon, fax dan internet yang lebih cepat.

Selain itu, pengawasan yang lebih juga harus diberikan pada kegiatan penerimaan barang, untuk meminimalkan resiko loss bahan baku yang mungkin terjadi. Para pemeriksa juga harus didorong untuk melakukan kegiatan pemeriksaan secara teliti. Pengetahuan mengenai jenis-jenis barang yang tidak dapat digunakan untuk bahan baku produksi juga harus diberikan untuk para pemeriksa.

\section{Analisis Masalah Tingginya Tingkat Kerusakan Barang Jadi}

Barang jadi merupakan salah satu barang yang paling penting yang ada di dalam perusahaan, karena barang jadi juga merupakan persediaan. Dengan adanya masalah barang jadi, maka perusahaan memiliki potensi kehilangan penjualan. Kerusakan barang jadi ini dapat disebabkan oleh beberapa hal, antara lain adalah kurang terjaganya kebersihan gudang. Kurang terjaganya kebersihan gudang dari 
material seperti debu dan air menyebabkan kerusakan terjadi pada barang jadi. Barang jadi yang mengalami kerusakan ada yang masih dapat dijual, tentunya dengan harga yang lebih murah. Barang jadi seperti ini dapat dikategorikan sebagai barang dengan kualitas dua. Kerusakan barang jadi menunjukkan adanya inefisiensi dan tentu saja membuat perusahaan mengalami kerugian, yang tentu jumlahnya tidak sedikit.

Dengan penerapan Just-In-time, masalah kerusakan barang jadi dapat diatasi. Sesuai prinsip Just-In-time, kebersihan merupakan suatu keharusan. Dengan kebersihan yang terjaga, terutama di gudang barang jadi, tentu saja tingkat kerusakan barang jadi akibat kondisi gudang yang kotor dapat dikurangi. Agar proses ini berjalan dengan baik, maka alat-alat kebersihan yang ada di gudang barang jadi akan ditambahkan. Selain itu, Just-In-time juga mengharuskan adanya perawatan berkala. Perawatan berkala juga akan dilakukan pada sarana memindakan barang jadi misalnya forklift. Dengan perawatan berkala yang baik, resiko kebocoran oli tentu dapat ditekan sehingga tingkat kerusakan barang jadi akibat kebocoran oli dapat diminimalkan. Selain itu, dengan penerapan Just-InTime, maka sparepart dan forklift tentu akan mendapatkan perhatian lebih karena adanya perawatan dan penggantian sparepart secara berkala.

\section{Analisis Masalah Proses Penerbitan Purchase Order}

Penerbitan purchase order merupakan proses awal yang terjadi dalam kegiatan operasi perusahaan. Namun, proses penerbitan purchase order yang memakan waktu yang lama tidak sesuai dengan prinsip Just-In-time. Sesuai dengan prinsip Just-In-time Purchasing, maka seharusnya proses penerbitan purchase order harus dilakukan secara singkat dan cepat. Selain itu, masalah ini juga tentunya mengganggu aliran persediaan yang dimiliki perusahaan. Perusahaan menghadapi kemungkinana terjadinya kekurangan persediaan karena proses penerbitan purchase order yang memakan waktu yang lama dapat mengakibatkan persediaan yang ada habis sebelum persediaan yang baru tiba. Sesuai dengan prinsip Just-In-Time, maka sebaiknya puchase order diterbitkan pada hari yang sama dengan dibuatnya rencan pembelian bahan baku. Hal ini dikarenakan dengan prinsip JustIn-Time, maka akan terdapat banyak pembelian bahan dalam satu bulan, bahkan sangat mungkin pembelian dilakukan setiap hari.

Ada beberapa alasan yang menyebabkan proses penerbitan purchase order dalam perusahaan yang memakan waktu yang lama. Banyaknya pihak-pihak yang harus dilalui dalam proses penerbitan purchase order merupakan salah satu alasannya. Dalam proses purchase order, pihak-pihak yang biasanya harus dilalui antara lain adalah Kepala bagian pembelian, kepala bagian produksi, direktur pabrik, direktur komersial, kepala gudang bahan. Lagipula untuk mendapatkan otorisasi satu pihak membutuhkan waktu yang cukup lama, apalagi jumlah yang harus otorisasi begitu banyak. Alasan lain yang menyebabkan proses penerbitan purchase order dalam perusahaan memakan waktu yang lama adalah banyaknya jumlah pemasok yang dimiliki perusahaan.

Oleh karena itu, penerapan Just-In-Time dapat mengatasi masalah ketidakefisienan yang terjadi dalam proses penerbitan purchase order dalam perusahaan. Hal pertama yang harus dilakukan setelah penerapan Just-In-Time adalah mengurangi jumlah pemasok. Kriteria yang dapat digunakan utuk memilih pemasok yang masih dipakai misalnya pemasok yang tingkat loss bahan baku yang paling sedikit, pemasok yang memberikan harga yang paling kompetitif, pemasok yang bahan bakunya berkualitas baik, pemasok yang mendukung kegiatan perusahaan, pemasok yang lokasinya tidak jauh dari lokasi perusahaan, dan pemasok yang selalu tepat waktu pengiriman bahan baku. Setelah jumlah pemasok dikurangi, langkah selanjutnya adalah membuat kontrak jangka panjang dengan para pemasok yang ada. Dalam kontrak jangka panjang tersebut, diatur mengenai: harga bahan baku, spesifikasi minimum bahan baku, kuantitas bahan baku tiap pengiriman, dan alat transportasi pengiriman. Cara ini merupakan cara yang sama yang digunakan dalam menghadapi masalah tingkat loss bahan baku yang tinggi pada pembahasan sebelumnya. 
Mengenai lamanya otorisasi yang membuat proses penerbitan purchase order dalam perusahaan menjadi lama, dapat diatasi dengan penerapan Just-In-Time. Setelah Just-In-Time diterapkan, maka manajemen juga harus ikut mendukung penerapan Just-In-Time tersebut, sehingga manajemen juga harus bekerja sesuai dengan prinsip Just-In-time yang ada. Jika Just-In-time telah diterapkan , maka otorisasi yang tadinya memakan waktu lama akan berkurang waktunya. Hal ini sesuai dengan prinsip Just-In-Time yang berfokus pada ketepatan waktu dan penghilangan kegiatankegiatan yang tidak memberikan nilai tambah bagi perusahaan.

\section{Analisis Masalah Proses Produksi yang Menghasilkan Barang Kualitas Dua}

Masalah yang dihadapi perusahaan yang menghasilkan barang dengan kualitas dua, tepat menerapkan Just-In-Time yang menekankan pada efisiensi. Perusahaan mengalami kerugian karena harga jual barang kualitas ini lebih murah dibandingkan dengan harga barang dengan kualitas satu (baik). Dengan diterapkannya Just-In-time, maka persentasi barang dengan kualitas dua akan menurun dan diharapkan menjadi $0 \%$ yang sesuai dengan prinsip Just-In-Time yang menekankan efisiensi.

\section{Penerapan Just-In-Time}

Dalam menerapkan Just-In-Time, perusahaan harus melakukan beberapa hal untuk menunjang proses penerapan Just-In-Time. Tujuannya adalah agar proses penerapan Just-In-time dapat berjalan dengan lancar dan cepat. Hal pertama yang harus dilakukan adalah mengedukasi dan melatih seluruh pihak yang ada dalam perusahaan. Hal ini perlu dilakukan agar pihak-pihak tersebut mengerti konsep dasar mengenai Just-In-Time dan agar mereka mengerti maksud dan tujuan perusahaan untuk menerapkan Just-In-Time. Dengan kemampuan dan pemahaman yang baik mengenai Just-In-time, maka seluruh pihak yang ada dapat membantu memperlancar proses penerapan Just-In-Time dalam perusahaan.

Hal lain yang harus dilakukan adalah menjadikan kualitas sebagai prioritas. Kualitas harus dijadikan prioritas karena sesuai dengan prinsip Just-In-Time yang mementingkan efisiensi namun tetap memperhatikan kualitas. Hal ini dikarenakan walaupun semua kegiatan yang ada dilakukan tepat waktu, tanpa kualitas yang baik semua yang dilakukan oleh perusahaan tentu menjadi sia-sia. Prioritas terhadap kualitas juga ditekankan karena sedikitnya persediaan yang dimiliki. Dengan sedikitnya persediaan, maka tingkat kesalahan juga harus diminimalkan. Jika timbul kesalahan, belum tentu persediaan yang ada dapat digunakan untuk menutup kesalahan tersebut. Hal berikut yang harus dilakukan adalah menjadikan para pekerja memiliki kemampuan yang beragam dan handal. Oleh karena itu, para pekerja yang ada dapat melakukan beberapa pekerjaan, tidah hanya terbatas pada bidang tertentu. Hal ini akan mendatangkan efisiensi bagi perusahaan karena beberapa pekerjaan dapat ditangani oleh satu orang, sehingga perusahaan tidak perlu mempekerjakan banyak pekerja.

Persediaan juga perlu diperhatikan, sesuai prinsip Just-In-time, maka persediaan yang dimiliki oleh perusahaan harus seminimum mungkin, bahkan jika mungkin tidak memiliki persediaan. Hal ini bertujuan untuk meningkatkan efisiensi dengan menekan biaya untuk menjalankan gudang-gudang yang ada. Selain itu, dengan sedikitnya persediaan, maka resiko kerusakan barang, baik bahan baku dan barang jadi dapat dikurangi. Jumlah pemasok yang dimiliki perusahaan juga harus dikurangi. Hal ini bertujuan untuk memilih pemasok-pemasok yang dapat membantu perusahaan dalam menerapkan metode Just-In-Time. Pemasok-pemasok yang akan dimiliki oleh perusahaan nantinya akan berjumlah sedikit. Para pemasok tersebut juga harus diikat dengan kontrak jangka panjang agar nantinya kegiatan operasi perusahaan tidak terhambat dan dapat tepat waktu.

\section{Kendala-Kendala yang Dihadapi dalam Penerapan Just-In-Time}

Dilihat dari kemampuan Just-In-time mengatasi masalah-masalah dalam perusahaan, maka sebaiknya perusahaan menerapkan Just-In-time agar masalah-masalah tersebut dapat cepat teratasi. 
Penerapan Just-In-Time dalam perusahaan tentu akan meningkatkan kemampuan dan efisiensi dalam perusahaan. Namun, proses penerapan Just-In-Time dalam perusahaan tentu akan menghadapi kendala. Kendala yang muncul ini merupakan hal yang wajar, karena penerapan sesuatu yang baru tidak mungkin berjalan dengan lancar.

kendala waktu. Hal ini dikarenakan untuk menerapkan Just-In-Time secara menyeluruh, dibutuhkan proses yang panjang dan waktu yang tidak sebentar. Pada awal penerapan Just-In-Time, tentu banyak kekurangan yang terjadi. Seiring dengan berjalannya waktu, baru kekurangankekurangan tersebut dapat diperbaiki sehingga pada akhirnya penerapan Just-In-Time dapat berjalan dengan baik; kendala pengaruh yang akan dirasakan oleh para pekerja karena adanya perubahan alur kerja dengan minimnya persediaan. Dengan metode Just-In-time para pekerja akan dituntut untuk bekerja secara sempurna karena tidak adanya persediaan dan kesalahan harus diperkecil seminimal mungkin; kendala munculnya resiko untuk kehilangan penjualan. Resiko kehilangan penjualan ini muncul karena tidak adanya persediaan dalam jumlah banyak. Dengan jumlah persediaan yang sedikit, maka jika terjadi kejadian yang tidak dapat diprediksi, seperti lonjakan permintaan, tentu perusahaan tidak akan sanggup memenuhi semua permintaan tersebut karena terbatasnya persediaan yang mereka miliki.

Kendala penerapan Just-In-Time yang dilakukan oleh perusahaan tidak didukung oleh pihakpihak eksternal yang berkaitan dengan perusahaan, yaitu pemasok-pemasok, jasa pengiriman barang jadi, dan sebagainya. Penerapan Just-In-time yang dilakukan oleh perusahaan akan menjadi sia-sia tanpa dukungan pihak eksternal. Hal ini dikarenakan proses yang berkaitan dengan pihak eksternal tersebut juga harus dilakukan secara cepat, berkualitas, dan tanpa kesalahan. Sedangkan jika pihak eksternal tersebut tidak menerapkan prinsip Just-In-Time, maka keinginan perusahaan agar proses tersebut berjalan dengan cepat. Berkualitas, dan tanpa kesalahan tentu sulit terwujud. Kendala-kendala yang mungkin akan dihadapi oleh perusahaan di atas, walaupun pada awalnya akan memberatkan perusahaan, namun akan dapat diatasi secara perlahan-lahan seiring berjalannya waktu. Kendalakandala tersebut harus dipandang sebagai proses penyempurnaan penerapan Just-In-Time, bukan sebagai masalah yang memberatkan. Terlebih dengan keuntungan yang akan didapatkan oleh perusahaan setelah menerapkan Just-In-Time.

\section{PENUTUP}

Berdasarkan pembahasan di atas, maka dapat diambil beberapa kesimpulan, antara lain: (1) Proses penerapan Just-In-Time dalam perusahaan harus memperhatikan beberapa hal, yaitu: mengedukasi dan melatih seluruh pihak yang ada dalam perusahaan, menjadikan kualitas sebagai prioritas, menjadikan para pekerja memiliki kemampuan yang beragam dan handal, memperhatikan persediaan, mengurangi jumlah pemasok. (2) Dalam proses penerapan Just-In-Time dalam penelitian ini, tentu ada kendala yang muncul, yang antar lain adalah: kendala waktu yang cukup lama, pengaruh yang akan dirasakan oleh para pekerja karena minimnya persediaan, munculnya resiko kehilangan penjualan, dan kemungkinan tidak mendukungnya pihak-pihak eksternal perusahaan.

\section{DAFTAR PUSTAKA}

Bannock, G., Baxter, R., \& Davis, E. (2003). Dictionary of economics. London: Profile Books.

Blocher, E. J., Chen, K. H., \& Lin, T. W. (2002). Cost management: a strategic emphasis (2nd ed.). New York: McGraw-Hill.

Hansen, D. R., \& Mowen, M. M. (2003). Cost management: accounting and control (4th ed.). United Stated of America: South-Western. 
Hansen, D. R., \& Mowen, M. M. (2006). Management accounting: the cornerstone for business decisions. United Stated of America: South-Western.

Hansen, D. R., \& Mowen, M. M. (2003). Management accounting (6th ed.). United Stated of America: South-Western.

Heizer, J., \& Render, B. (2001). Principles of operation management (6th ed.). New Jersey: PrenticeHall.

Hernandez, A. (1993). Just-In-time quality: a practical approach. New Jersey: Prentice Hall.

Hilton, R. W., Maher, M. W., \& Selto, F. H. (2000). Cost management: strategies for business decision. United States of America: McGraw-Hill.

Honren, S., \& Stratton. (2002). Introduction to management accounting (12th ed.). New Jersey: Pearson Education.

Library of Congress Cataloging-Publication Data. (1999). Total quality management: text, cases and reading (3rd ed.). United States of America: CRC Press LCC.

Modarress, B., \& Ansari, A. (1990). Just-In-time purchasing. New York: The Free Press.

Narasimhan, S. L., McLeavey, D. W., \& Billington, P. J. (1995). Production planning and inventory control (2nd ed.). New Jersey: Prentice-Hall.

Petroff, J. N. (1993). Handbook of MRP II and JIT: strategies for total manufacturing control. New Jersey: Prentice-Hall.

Schniederjans, M. J. (1993). Topics in Just-In-Time management. Massachusetts: Allyn \& Bacon.

Silver, E. A., Pyke, D. F., \& Peterson, R. (1998). Inventory management and production planning and scheduling. United States of America: John Wiley \& Sons.

\section{RIWAYAT PENULIS}

Heri sukendar W. lahir di Jakarta, pada tanggal 25 Januari 1966, penulis menamatkan pendidikan S1 di Universitas Tarumanagara Fakultas Ekonomi Jurusan akuntansi, sedangkan pendidikan S2 penulis mendapatkan beasiswa di Universitas Trisakti, Magister Manajemen Jurusan Keuangan. Saat ini bekerja sebagai Manager Akuntansi di sebuah Grup Perusahaan Swasta. Penulis aktif sebagai Faculty Member SCS di Universitas Bina Nusantara. 